Review

\title{
Agricultural Use of Sewage Sludge as a Threat of Microplastic (MP) Spread in the Environment and the Role of Governance
}

\author{
Natalia Milojevic and Agnieszka Cydzik-Kwiatkowska *
}

check for updates

Citation: Milojevic, N.; CydzikKwiatkowska, A. Agricultural Use of Sewage Sludge as a Threat of Microplastic (MP) Spread in the Environment and the Role of Governance. Energies 2021, 14, 6293. https://doi.org/10.3390/en14196293

Academic Editor: Kazi Parvez Fattah

Received: 30 August 2021

Accepted: 30 September 2021

Published: 2 October 2021

Publisher's Note: MDPI stays neutral with regard to jurisdictional claims in published maps and institutional affiliations.

Copyright: (c) 2021 by the authors. Licensee MDPI, Basel, Switzerland. This article is an open access article distributed under the terms and conditions of the Creative Commons Attribution (CC BY) license (https:/ / creativecommons.org/licenses/by/ $4.0 /)$.
Department of Environmental Biotechnology, Faculty of Geoengineering, University of Warmia and Mazury in Olsztyn, 10-709 Olsztyn, Poland; nataliamilojevic97@gmail.com

* Correspondence: agnieszka.cydzik@uwm.edu.pl; Tel.: +48-8952-34194

\begin{abstract}
Sewage sludge from wastewater treatment plants is commonly used as a soil amendment on agricultural land. Unfortunately, more and more research indicates that large amounts of microplastic (MP) are re-introduced to soil with sludge. This study aims to present the impact MP has on soil ecosystems, global trends in agricultural sludge management resulting from a high concentration of micropollutants in sludge, and finally propose a high-level strategy for sustainable sludge management. This strategy is mostly dedicated to the European Union and involves multiple stakeholders and the links between each of them to achieve appropriate sludge management to avoid soil pollution with MP. Governance, Technology, Consumer Acceptance, and Economy and Commercial Viability is explored in depth. To the author's knowledge, this is the first paper to discuss these topics in the context of a changing agricultural scene and identifies ways of which sewage sludge can limit MP pollution whilst still fitting into a circular economy. As total elimination of agriculturally used sludge is not a viable option, more stringent regulation on sludge quality before its use is necessary, especially on contaminant concentrations. This includes MPs limits, to improve sludge quality, in turn improving soil health. More alternative management options for sludge that does not meet land usage requirements are necessary and will be explored in this study. Overall, the combination of factors discussed will inevitably lead to more emphasis on sewage sludge management, therefore it can be expected that the information presented in this review will be of high demand and importance for sludge producers and serves as a comprehensive foundation for researchers to build off.
\end{abstract}

Keywords: soil contamination; sustainable sludge management; legislation

\section{Introduction}

Plastics are materials formed by polymers and additives which are characterized by high molecular weight [1]. Global production of plastic in 2019 has reached almost 370 million tonnes [2]. The characteristics that make them an attractive material used extensively throughout society include durability, waterproofness, and resistance to wear [3]. Plastics demand in Europe by segment are as follows: packaging (39.6\%), building \& construction $(20.4 \%)$, automotive $(9.6 \%)$, electrical \& electronic $(6.2 \%)$, household, leisure \& sports $(4.1 \%)$, agriculture $(3.4 \%)$ and other $(16.7 \%)$ which includes furniture, appliances, mechanical engineering, medical and more [2]. The most common plastics include 19.4\%-polypropylene (PP), 17.4\%-polyethylene low-density \& linear low-density (PE-LD/PE-LLD), 12.4\% - polyethylene high density \& medium density (PE-HD/PE-MD), 10\%-polyvinylchloride (PVC), 7.9\%—polyurethane (PUR), 7.9\%-polyethylene terephthalate (PET), 6.2\% polystyrene \& expanded polystyrene (PS + EPS) and 7.5\% other plastics [2]. Despite an increase in awareness about the environmental consequences of plastic; the majority is still being released into the environment [4]. In the USA alone, the recycling rate of plastics is only $8 \%$ [5].

Microplastic (MP) is defined as a synthetic polymer with a particle size diameter of $<5 \mathrm{~mm}$ [6]. Primary MPs produced in the micrometer size range by industry are mostly used 
in personal care products (PCPs) [7]. The total annual release of primary MPs, which are mostly composed of polyethylene, by its main producers i.e., Europe, USA, and China is over 3800 tons [7]. Another significant source of primary MPs is synthetic fibers from clothing and textiles. The chemical and mechanical stresses from the washing process that fabrics undergo during the cycle are the main cause of the release of MPs from synthetic clothing. Washing machines produce a waste effluent that contains released fibers. A recent study by Napper and Thompson [8] indicated that washing $6 \mathrm{~kg}$ of clothing could result in the release of more than 700,000 microfibers, which in most developed countries travels via the wastewater column to wastewater/sludge treatment plants. Synthetic fibers are responsible for about $60 \%$ of the total global microfiber production and the use of these synthetics in the textile industry has dramatically increased to almost 50 million tons in 2010 from 2.1 million tons in 1950 [9]. As textile production continues to increase, as well as increase accessibility to fast fashion, the number of synthetic fibers entering and passing wastewater treatment plants (WWTPs) will inevitably increase [9]. Another source of MPs is spilled from plastic pre-production plants; drains have been implemented to counteract this however enforcement is lacking $[10,11]$. Secondary MPs result from the breakdown of meso- and macroplastic litter due to physical (e.g., ultraviolet radiation), chemical, and biological factors [4]. In marine environments, plastic fragmentation is induced by wave action and sunlight [3]. Fragmentation of plastics on land, especially at the soil surface, occurs readily due to exposure to UV radiation from sunlight and temperature fluctuations which are more commonly greater than those in seawater [3]. The spread of MPs in the environment results mainly from wind and wave action [9]. The characteristics of plastics such as high molecular weight, hydrophobicity, and crosslinked structure, means that MPs can withstand biodegradation and persist in the environment for decades or longer. Although biodegradation is possible, it is reliant on specific degrading organisms (Ideonella sakaiensis 201-F6, Thermobifida sp., Thermomonospora $\mathrm{sp}$.) that can degrade particular polymers through conditions that may not necessarily be encountered in nature [3,12].

MPs are now one of the most complex environmental problems that need immediate attention. MPs can be found almost ubiquitously in all parts of aquatic and terrestrial environments as well as in air and food [13]. The United Nations Environmental Programme (UNEP) estimates that 18,000 pieces of plastic litter exist per square kilometer of the ocean [14]. A mid-point estimate of 0.95 million tonnes of MPs per annum is released into the ocean [15]. Plastics have now been documented in some of the most remote areas of the world including Mount Everest, Antarctic region, and encapsulated in Arctic Sea ice, deep-sea sediment, and submarine canyons $[3,7,9]$.

Previous literature focusing on problems related to MP presence in SS and its use on agricultural land was presented in Table S1 (Supplementary Materials). The reviews presented the analytical methods for MP analysis in SS, abundance, types of MP in sludge, and the fate and transport of MPs in the environment as a result of sludge disposal. Prior publications focused on the legislation of SS have addressed current frameworks around the world in terms of SS disposal on land. What is lacking is a forecast into the future based on perceptions surrounding SS disposal on land, agricultural challenges, and alternatives that fit into a circular economy. Therefore, this review will fill in this research gap and provide a proposed high-level strategy for sustainable SS management that has not been offered previously. The literature review conducted for this study relied upon gathering previously published papers in peer-reviewed journals that contained keywords related to this paper (Table S2, Supplementary Materials).

\section{Treating MPs at the Source-Preventing MPs into Waterways}

Solutions to tackle MP release from clothing have been vast, from the use of "guppy bags" which are used to store clothing during the wash cycle and capture the MPs, to the use of protective finishing treatments on synthetic clothing. For example, a recent study developed a protective coating based on the use of pectin which was observed to reduce almost $90 \%$ 
of the number of MPs released by the untreated polyamide [16]. It was also observed that using fabric softener during the washing cycle, on woven polyester, decreased the friction among fibers in clothing, therefore, reducing MP release by more than $35 \%$ when compared to only using a liquid detergent. However, this is contradicted by a study performed by Chiweshe and Crews [17] where it was observed that the use of fabric conditioner increased the release of MP fibers when washing woven polyester. There is currently a lack of incentives for manufacturers to design textiles and clothing which either don't include or minimize the shedding impact of MPs. Washing machine filters have gained a lot of interest in recent years as an effective way to capture MPs before they enter the effluent water from a washing machine. France has adopted a law that aims to fit every newly manufactured washing machine with an MP filter by 2025 [18]. Public pressure is forcing other countries to follow suit with similar legislation. A report for the DG Environmental of the European Commission stated that the cost-effectiveness of capturing MPs in a washing machine versus at a WWTP for textiles is very comparable. However, the former option is more attractive as it eliminates the need to capture MPs in sludge and the cost-effectiveness of infrastructure improvements to WWTP would decrease significantly if MP reduction measures were to be implemented [19]. The report concluded by stating each MP source has more associated cost-effective preventative solutions and would therefore be more appropriate to focus on prevention.

Prevention of MPs found in personal care products has been promising in recent years. Alternatives to MPs include silica, perlite, and microcrystalline cellulose. The presence of these solutions makes it easier for companies to implement and adapt [20]. Legislation has been positively responsible for the cease of industry-produced MPs in such products, for example, the UK's ban on MPs in cosmetics in 2017 and the USA 'Microbead-Free Waters Act" of 2015 [21,22]. Major cosmetic companies in the EU such as Colgate-Palmolive, Unilever, Boots, or L'Oréal have also voluntarily ceased the use of MPs in their products. In 2015, UNEP called for a ban and eventual phase-out on the use of MPs in cosmetics and PCPs [22]. The European Chemicals Agency (ECHA) is proposing to restrict MPs in products in the EU/EEA (European Economic Area) which would prevent the release of 500,000 tonnes of MP into the environment over 20 years [23]. If agreed upon, the restriction would be adapted in 2021 or 2022 according to the ECHA [23]. However, the ban does not come as a simple solution as there have been some problems when excluding and including biodegradable plastics as well as whether or not to set a lower limit [10]. Overall, implementing legislative changes to MP production is a vital source of control that would foster significant outcomes.

Another source of MPs found in WWTP comes from spills that occur at pre-plastic production plants. Their release into the environment can occur at any time stage during the production chain [11]. The addition of drains on the premises to avoid pollution has been implemented in some factories, however, this needs greater legislative enforcement [10]. Table 1 shows an overview of the sources of MP pollution and examples of suggested strategies.

Table 1. Sources of MP pollution and examples of suggested strategies (adapted from [10], with modifications); type: Preventative $(\mathrm{P}) \rightarrow$ e.g., legislation or behavioral change, decentralized treatment $(\mathrm{D}) \rightarrow$ at the source or in the urban area, centralized treatment $(\mathrm{C}) \rightarrow$ at the WWTP.

\begin{tabular}{|c|c|c|c|c|c|}
\hline Source & Pathway & $\begin{array}{l}\text { Suggested Measures } \\
\text { and Strategies }\end{array}$ & Type & Responsibility & $\begin{array}{c}\text { Pollution } \\
\text { Movement }\end{array}$ \\
\hline Microbeads in PCP's & Wastewater & Ban/substitution & $\mathrm{P}$ & $\begin{array}{l}\text { Producer and authorities } \\
\text { for decision and compliance }\end{array}$ & None \\
\hline
\end{tabular}


Table 1. Cont.

\begin{tabular}{|c|c|c|c|c|c|}
\hline Source & Pathway & $\begin{array}{l}\text { Suggested Measures } \\
\text { and Strategies }\end{array}$ & Type & Responsibility & $\begin{array}{l}\text { Pollution } \\
\text { Movement }\end{array}$ \\
\hline \multirow{3}{*}{ Laundry } & \multirow{3}{*}{ Wastewater } & $\begin{array}{l}\text { Change in practice: } \\
\text { textile constructions }\end{array}$ & $\mathrm{P}$ & Producer & \multirow[b]{2}{*}{ None } \\
\hline & & $\begin{array}{l}\text { Change in practice: } \\
\text { pre-washings }\end{array}$ & $\mathrm{D}$ & $\begin{array}{l}\text { Producer and authorities for } \\
\text { assuring compliance }\end{array}$ & \\
\hline & & $\begin{array}{l}\text { Change in washing and } \\
\text { consumption behavior } \\
\text { Filter in the } \\
\text { washing machine }\end{array}$ & $\mathrm{D}$ & $\begin{array}{l}\text { Citizens } \\
\text { Produce and citizens for } \\
\text { correct use }\end{array}$ & $\begin{array}{l}\text { Wastewater to } \\
\text { solid waste }\end{array}$ \\
\hline \multirow{2}{*}{$\begin{array}{l}\text { Plastic pre- } \\
\text { production plants }\end{array}$} & \multirow{2}{*}{$\begin{array}{l}\text { Wastewater/ } \\
\text { stormwater }\end{array}$} & Enforcement of legislation & $\mathrm{P}$ & Authorities & None \\
\hline & & Drain filters & $\mathrm{D}$ & $\begin{array}{l}\text { Factories for use and authorities } \\
\text { for assuring function }\end{array}$ & $\begin{array}{l}\text { Wastewater to } \\
\text { solid waste }\end{array}$ \\
\hline
\end{tabular}

\section{Microplastics in Sewage Sludge from WWTPs}

The route of MPs into the environment is either through wastewater treatment plants (WWTPs) or without treatment, leading straight into waterways [7]. Considering that $80 \%$ of the world's wastewater goes untreated [24], even if solutions such as removing MPs directly from the WWTP or appropriately managing sludge in the context of MPs are enforced, the significance may not be as big if only $20 \%$ of wastewater is being treated.

WWTPs receive MPs with domestic and industrial wastewater and stormwater. Conventional WWTPs have been shown to eliminate a high percentage of MPs, however, this is very much dependent on the treatment processes. Table 2 shows retention rates of MPs from effluent water in WWTPs and the treatment level associated. The removal of MPs from the final effluent close to $100 \%$ can be ensured by membrane processes or sand filtration [19]. Independent of the applied treatment, due to MP resistance to biodegradation, the majority of MP sinks into sewage sludge which is produced as a by-product of the biological treatment [25].

Table 2. WWTP MPs retention depending on treatment level adapted from [19], with modifications.

\begin{tabular}{ccc}
\hline WWTP Sites & Treatment Level & Removal Rate \\
\hline Netherlands (7 WWTPs) & Tertiary & $72 \%$ \\
\hline Denmark (10 WWTPs) & Tertiary & $99.7 \%$ \\
\hline \multirow{2}{*}{ Australia (3 WWTPs) } & Tertiary & $>90 \%$ \\
& Secondary & $29 \%$ \\
& Primary & $17 \%$ \\
\hline Germany (1 WWTP) & Tertiary & $97 \%$ \\
\hline \multirow{2}{*}{ USA (3 WWTPs) } & Tertiary & $99 \%$ \\
& Secondary & $96 \%$ \\
\hline \multirow{2}{*}{ UK (1 WWTP) } & Secondary & $98 \%$ \\
\hline USA (7 WWTPs) & Primary & $78 \%$ \\
\hline Finland (1 WWTP) & Tertiary & $90 \%$ \\
\hline
\end{tabular}

MP removal technology should prevent MPs from entering both effluent and sludge, especially if the sludge is used for agricultural purposes [19]. However, one of the major obstacles to the development of such technologies is the lack of standard protocol to measure the capture rate of MPs and therefore identify best practices in their removal from effluent and sludge. Currently, there is no standardized protocol to report MP content; MPs are being classified per weight, surface area, per volume, or as a weight ratio; there is 
also no consistent definition with no upper nor lower size limit. This ultimately means that MPs are subject to a broad definition and can refer to a wide range of polymers, particle sizes, and densities all of which hinder comparison ability between studies [3,26]. Therefore, there is great importance in the creation of generalized and standardized units for efficient MPs reporting for comparison and data exchanges [27]. Fourier Transform Infrared (FTIR) and Raman spectroscopy are the most common analytical methods used to identify MP samples [28]. However, the use of both methods may be necessary for some instances e.g., for reliable characterization of colored particles. Additionally, FTIR can produce an underestimation of MPs, especially for MPs $<20 \mathrm{um}$, when compared to Raman spectroscopy [28]. Sample contamination during picture analysis has been addressed among many MP studies; to combat this disruption it is recommended to take larger samples of soil and sludge [27]. Visual sorting of MPs allows for human error as it is based upon the operator's criteria and judgment. To account for this, recommendations to reduce false negatives include combining the visual sorting with spectroscopic approaches, however, this increases the cost and complexities of the assessments [29]. A statement published by Australian and New Zealand Biosolids Partnership [30] acknowledged research into the impacts of MPs in soils however it was mentioned that there is a need for standardized analysis methods and the lack of results in difficultly in gathering reliable estimates for loads of MPs [30]. Overall, it is clear that standardization is fundamental to not only achieve reliable results but to have them acknowledge by regulatory bodies. The European Commission's science and knowledge service, The Joint Research Centre (JRC), which provides independent scientific advice and support to EU policy, is working on creating a more standardized protocol for MPs. The JRC is working on an inter-laboratory comparison study to determine MPs in water samples to help identify potential methods for further standardization of measurements of MPs [31].

Sewage sludge management's importance is intensifying [32] as sludge production is increasing with population increases, urbanization, and industrialization, increasing the capacity of WWTP, a greater adaptation of advanced methods of wastewater treatment, increased level of the sewer connection, and construction of new and upgraded facilities [33]. The most commonly applied sludge management techniques worldwide include:

- $\quad$ use in agriculture (as fertilizer and soil amendment),

- thermal treatment (incineration, pyrolysis, gasification),

- landfilling,

- $\quad$ stockpiling,

- $\quad$ production of compost (used in landscaping, parks, and gardens),

- $\quad$ remediation (on eroded or polluted land),

- energy generation,

- $\quad$ ocean dumping (now banned in most countries).

The Sewage Sludge Directive 86/278/EEC requires the pretreatment of sludge to reduce organic content and remove pathogens and contaminants before its use on land. Common pre-treatment methods include anaerobic digestion, composting, lime stabilization, and thermal treatment. Stabilized sludge is called biosolids (BS) and the most common and economical way of its management is used as a fertilizer on agricultural lands to stimulate plant growth [34]. Rates of BS recycling in agriculture around the globe are presented in Table 3. As can be concluded, very high loads of MPs enter soil together with BS. van den Berg et al. [27] reported that on average, a 256\% higher MP content was observed in soils with a history of SS application in comparison to soils with no application of sludge. Sludge is not only an accumulator for MPs but may also contain toxic organic and inorganic pollutants, pathogens, heavy metals, and toxic compounds such as pesticides $[35,36]$. The accumulation of such toxic components, therefore, poses a threat to the ecosystems to which it is exposed [37]. 
Table 3. Estimated weight of MPs added to agricultural soils in Australia, China, the European Union, the USA, and Canada; adapted from [38], with modifications.

\begin{tabular}{ccccc}
\hline Location & $\begin{array}{c}\text { BS Production } \\
\text { (Tonnes) }\end{array}$ & $\begin{array}{c}\text { Estimated BS Used } \\
\text { in Agriculture Soils }\end{array}$ & $\begin{array}{c}\text { Estimated Minimum Weight of } \\
\text { MPs Added to Agricultural Soils } \\
\text { from BS (Tonnes/Year) }\end{array}$ & $\begin{array}{c}\text { Estimated Maximum Weight of } \\
\text { MPs Added to Agricultural } \\
\text { Soils from BS (Tonnes/Year) }\end{array}$ \\
\hline Australia & 327,000 & $75 \%$ & 1241 & 7170 \\
\hline China & $6,000,000$ & $45 \%$ & 13,660 & 78,930 \\
\hline $\begin{array}{c}\text { European } \\
\text { Union }\end{array}$ & $11,000,000$ & $47 \%$ & 26,156 & 151,137 \\
\hline USA & $7,000,000$ & $60 \%$ & 21,249 & 122,780 \\
\hline Canada & 500,000 & $60 \%$ & 1518 & 8770 \\
\hline
\end{tabular}

Once MPs are released into soil environments, several ways can determine their fate into other environments such as aquatic. The practice of tillage used in farming can shift MPs from the topsoil into deeper topsoil and the plow layer; smaller particles are also more likely to undergo vertical movement than larger ones [4,39,40]. Rillig et al. [40] observed that anecic earthworms were able to transport PE MP particles $10 \mathrm{~cm}$ deep into a soil profile from the surface. Similarly, Maaß et al. [41] provided evidence that MP particles are moved and distributed by collembolan and suggested MPs can be translocated at the same distance and speed as organic matter. Vertical transportation of MPs in the soil by these means allows MPs to enter groundwater and accumulate or travel into aquatic or marine environments. Other methods of travel into these environments include surface water, run-off, rivers, lakes, and buffer zones around freshwater bodies (Figure 1). Therefore, the management procedure of sewage sludge determines the next pathway of these MPs, and mismanagement can result in MP pollution to soil, air, and surface water [25].

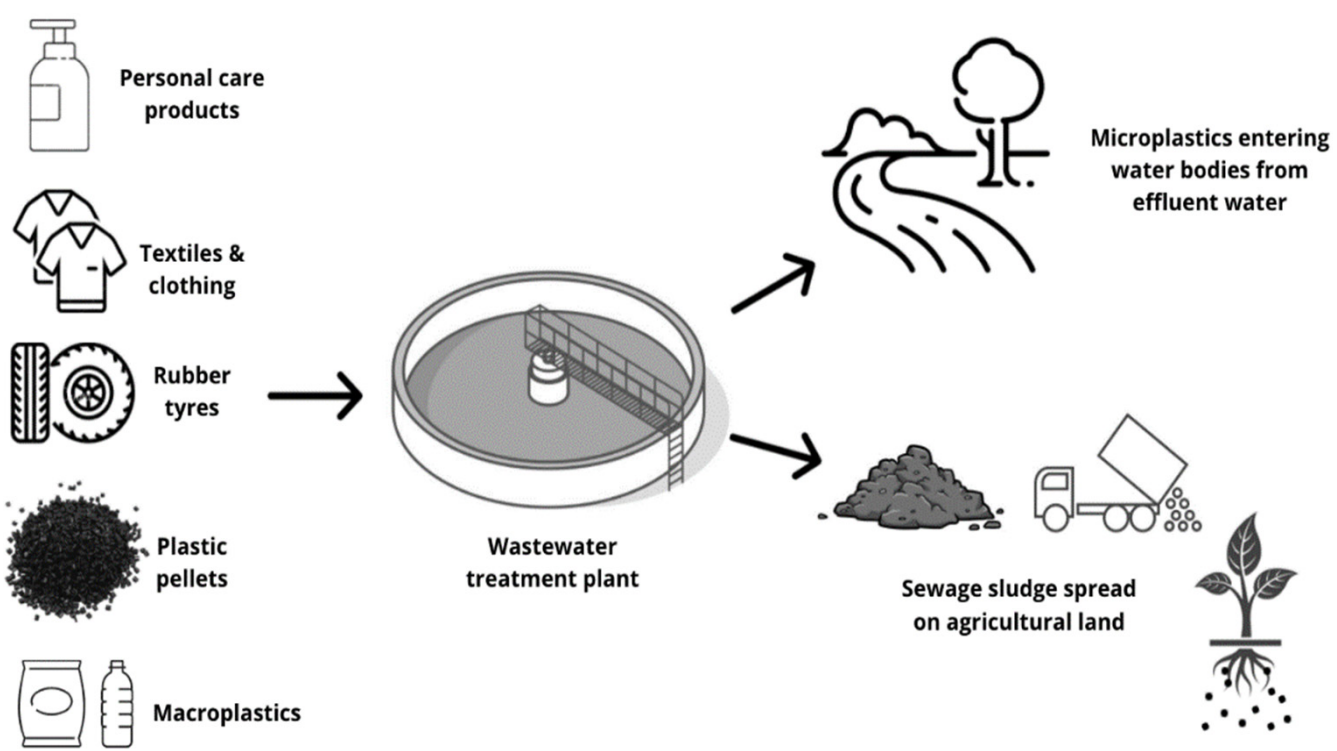

Figure 1. Environmental risks associated with sewage sludge reuse.

\section{Forecast into Agricultural Industry}

To evaluate alternative methods for sustainable sludge disposal in the context of emerging contaminants such as MPs, a forecast is needed into the industries for which it is currently used, as well as the industries for which it has the potential to enter. Intensive agriculture has had devastating impacts on soil fertility and is a well-acknowledged source of greenhouse gases (GHG) emissions which therefore have damaging effects on the environment [42]. The gains from the Green Revolution were often accompanied 
by damaging effects on agricultural land including loss of soil fertility, erosion of biodiversity, and land degradation [43]. Still, in today's conventional farming approach, soils are experiencing increased losses of carbon during cultivation and decreased ability to retain new carbon, overall leading to a net loss of soil carbon [44]. Soil has a significantly greater carbon storage potential than the atmosphere and the biotic pool combined, with 3.2 times and 4 times greater storage, respectively. However, it is now estimated that most agricultural soils have lost $40-60 \%$ of that initial soil organic carbon $[44,45]$. Soil erosion and water depletion cost $\$ 400$ billion globally, of which $96 \%$ of that comes from food production [46]. Estimations by the The Food and Agriculture Organization of the United Nations suggest that there are approximately only 60 years of fertile soil left, while agriculture and global food demand are ever-increasing due to an increasing population. In recent years, there has been an increase in the adoption of conservation and regenerative agriculture, with approximately $8 \%$ of the total world cropland practicing conservation agriculture worldwide [46]. Project Drawdown—a comprehensive summary of the most viable solutions to climate change-lists Regenerative Agriculture (RA) as the 11th most impactful solution to draw the climate back down. RA is an approach to farming that uses soil conservation as the entry point to regenerate and contribute to multiple ecosystem services [47]. By regenerative/organic standards, BS are restricted for use on land. Alternatives used in RA, to compensate for the missing quantity of humus or soil imbalance usually provided by this BS, includes compost (from food scraps, animal manures, leaves, straw), biochar, bio-waste, intelligent humus management via the use of crop rotation methods, and manure fertilizers such as manure and fermentation residues [48]. Such changes in soil amendment use have already been carried out across Germany and alternatives must comply with the Federal Soil Protection Act [48]. Organic farming fosters higher levels of humified sequestered carbon, $4.1 \%$ compared to $2.85 \%$ in conventional practices (\% of total soil volume) [42]. BS has been observed to affect soil temperature, soil water content, and soil aeration, all of which can affect GHG emissions from soil. A study conducted by Wijesekara et al. [49] observed increased $\mathrm{CO}_{2}$ emissions from soil sites treated with BS, therefore restricting its carbon sequestration potential. BS has the potential to compromise the dynamic equilibrium of biological systems in soil due to the organic pollutants it contains, resulting in increased species loss in soil caused by competitive exclusion [50,51]. Excessive application of SS can lead to leaching and transport of nutrients as well as increasing the bioavailability of heavy metals that harm soil [52]. Overall, a considerable body of research points towards increased GHG emissions from the application of BS on agricultural land. On the other hand, conservation agriculture still encourages the use of BS/SS due to the nutrients it provides. Additionally, countries that are prone to drought, such as Australia, rely heavily on sewage sludge for moisture and to boost drought tolerance of vegetation; therefore, the phase-out of sewage sludge is not a viable option for such environments [53].

The current EU Directive (86/278/EEC) in many cases has been criticized as being too lenient on the limit values for heavy metals whilst absent in limit values for organic compounds and pathogens. The re-evaluation for the Directive in 2021 is expected to adopt more stringent requirements; this will allow for improvements in BS, which in turn will foster improved soil health. However, this also will mean that inevitably there will be more SS/BS which do not meet requirements and therefore will need alternative management options available. As more observations on the impacts of BS on land are documented, more countries e.g., Germany, are implementing further stringent regulations on its use for land application which is resulting in a steady decrease in the use of BS for agricultural application. Additionally, the availability of agricultural land and population density of countries is limiting the use of BS on land. The low level of acceptance by farmers and the public has also led to limited and decreased use in BS disposal for agriculture (Figure 2) [54]. Public acceptance of SS use on land is also challenging on a global scale due to the view of SS being a harmful waste derived from human excreta [55]. Lastly, over the last few decades, SS has gained more recognition in its use as an energy resource 
or material to fit into a circular model economy. Therefore, in this frame, keeping in mind the effects of sludge on land and its decreasing use as a soil amendment, the focus should now be on improving the quality of BS so it is appropriate for land application as well as having alternative methods ready for when BS do not meet appropriate quality levels.

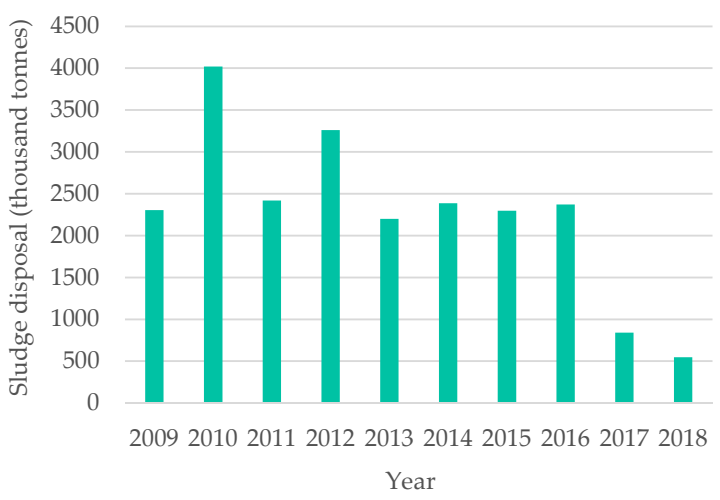

Figure 2. Sludge disposal in Europe-agricultural use Eurostat, [56].

There are no one-size-solution fits all approach; management of sewage sludge is very much dependent on the local and regional context. A total ban on the use of SS on land, especially within the EU, is not a viable possibility. Such a ban would suggest that current alternatives and infrastructure have sufficient capacity to process all sludge currently produced [57]. This however is not the case, especially considering countries including Ireland, Croatia, Cyprus, Latvia, Lithuania, Malta, and Romania have low rates of sewage sludge incineration and established infrastructure. Additionally, sewage sludge application may be appropriate for specific land depending on local conditions and requirements; countries most affected by this ban would be France, the UK, Ireland, Luxembourg, Hungary, and Spain, whose predominant use of sewage sludge is on land [43]. From an economic standpoint, a positive net cost-benefit from the transition from land application of sewage sludge to alternative methods is unlikely to be achievable for most European countries [57]. The main costs would be associated with financial and environmental costs from increased incineration and management e.g., from transport and emissions. For example, the total costs for incineration (mono-incineration) compared to land-spreading of semisolid digested SS is $417 € / \mathrm{tDS}$ and $134 € / \mathrm{tDS}$, respectively (Table 4).

Table 4. Net cost of sludge incineration and sludge recycling ( $€ / t D S)$, adopted from [57], with modifications.

\begin{tabular}{ccccc}
\hline & \multicolumn{2}{c}{ Incineration } & \multicolumn{2}{c}{ Sludge Recycling } \\
\hline Cost & Mono-Incineration & Co-Incineration & $\begin{array}{c}\text { Land-Spreading of } \\
\text { Semisolid Digested Sludge }\end{array}$ & $\begin{array}{c}\text { Land-Spreading of } \\
\text { Composted Sludge }\end{array}$ \\
\hline Internal cost-investment & 161 & 62 & 68 & 120 \\
\hline $\begin{array}{c}\text { Internal cost-operational } \\
\text { Internal benefits- }\end{array}$ & 213 & 228 & -63 & -63 \\
fertilizer replacement & - & - & 11 & 13 \\
\hline External cost & 37 & 41 & -6 & -6 \\
\hline $\begin{array}{c}\text { External benefits- } \\
\text { fertilizer replacement }\end{array}$ & - & - & 134 & 280 \\
\hline Total costs & 417 & 339 & & 124 \\
\hline
\end{tabular}




\section{Legislation, Regulation and Governance concerning Microplastic Pollution}

The ultimate goal with governance globally is to enforce appropriate legislation which minimizes the adverse impact of sludge on soil health, promotes the recycling and re-use of sewage sludge to its fullest potential, whilst minimizing the spread and accumulation of MP. The establishment of such legislation will restrict MP inputs into agricultural soil while contributing to a circular economy. Currently, no regulations or legislation exist that require the removal of MPs from the wastewater treatment process, sewage sludge, or BS. Neither the European Directive (EU 86/278/EEC) nor other regulations around the world regarding sewage sludge or BS consider MP as an unwanted pollutant [26]. In addition to MPs, other unregulated pollutants such as antibiotic residues, nanomaterials, tributyltin, total petroleum hydrocarbons, and various pathogens may therefore exist in sewage sludge at concerning concentrations [48]. However, it should also be acknowledged that population density and availability of agricultural land also plays a prominent role in influencing regulation at a national level [54]. Due to the gaps in EU policy, certain Member States have implemented more stringent national regulations for sludge. Countries such as Germany, the Netherlands, and Belgium have introduced much stricter limit values than what is required in the EU Directive 86/278/EEC [58]. The frameworks which include EU policy surrounding SS management have been examined and are presented in Table 5.

Table 5. Frameworks examining EU policy surrounding SS management.

\begin{tabular}{c}
\hline Framework \\
\hline Sewage Sludge Directive $86 / 278 /$ EEC
\end{tabular}

\section{Description}

At an EU level, sludge reuse in agriculture is governed by the 1986 Sewage Sludge Directive (86/278/EEC) which sets the regulatory framework for the agricultural use of SS, SS compost, and SS mixes [59]. In this directive, SS is prohibited for the use on land on which vegetables and fruits are grown and on grazing and pastureland. MP pollution is not mentioned in the directive either (EUR-Lex Council, 1986). Despite the absence of limit values for organic compounds and pathogens, several member states have added limit requirements and implemented stricter regulations that the directive states [54].

Urban Waste Water Treatment Directive $91 / 271 /$ EEC
The Urban Waste Water treatment directive establishes regulations on discharges of urban wastewater and from certain industrial discharges. This directive is in line with promoting a circular economy, where sludge recycling is encouraged whilst ensuring minimal adverse effects to the receiving environment. It also requires the publishing of situation reports on the disposal of SS every two years by relevant authorities or bodies in the Member States.

The Industrial Emissions Directive (2027/75/EU) (IED) establishes regulations around pollutant emissions from industrial installations. The directive does not apply to WWTPs however its application for SS remains uncertain [60]. The Waste Framework Directive (2008/98/EC) (WaFD) sets regulations related to waste management. The directive explains how to classify waste and by-products and knowing when waste ceases to be waste and becomes a secondary raw material (EUR-Lex Council, 2008). SS is not mentioned within the directive, therefore the extent to which sludge processing activities are covered is unclear. In 2015, the European Commission released a Circular Economy Plan called "Closing the loop-An EU Action Plan for the Circular Economy" (COM/2015/0614). The action plan aims to cover "the whole cycle": from production and consumption to waste management and the market for secondary raw materials.

Despite almost all sectors of the economy and related waste being acknowledged, SS lacks any recognition.

The recognition of an increase in pollutant concentrations in sludge as well as the desire to promote increased amounts of $P$ recovery has led to the use of thermal treatment as a primary sludge management solution [58]. Germany is among the top producers of sludge in the EU with approximately 1.77 Mt TS sewage sludge disposed of in 2016, with two-thirds of its sewage sludge being thermally treated (co- or mono- incineration) [48]. The Sewage Sludge Ordinance in Germany states that sewage sludge from WWTP will no longer be permitted for direct use as fertilizer from 1 January 2029. It is also required after 
this date that $\mathrm{P}$ is to be recovered from SS which contains at least $20 \mathrm{~g}$ per kilogram $(\mathrm{g} / \mathrm{kg})$ dry matter of $P$.

Outside of the EU, there are significant differences in how countries choose to treat their sewage sludge. Agricultural use is popular in Australia, New Zealand, and the USA with the former two having a limited application of any thermal treatment while the USA is increasingly starting to promote a re-direction towards the use of thermal [55]. New Zealand and Australia both share a legislation policy, the Australian and New Zealand Biosolids Partnership [30], which released a preliminary report on Microplastics Risk for the Australian and New Zealand Biosolids Industry in July 2020. The report acknowledged research into the impacts of MPs in soils, however, concluded that MP is unlikely to cause appreciable risk and that the benefits of BS application outweigh risks of the land application of BS due to MPs [30].

Japan has considerable influence over the progression and unfolding of sustainable sewage sludge management which has led other countries to follow suit. Agricultural use of sewage sludge is not widely practiced while thermal treatment accounts for $>70 \%$ of sewage sludge management. P recovery and recycling SS residues into building materials, compost, or soil amending products is also highly promoted [55]. Japan's efficiency in moving in a progressive manner of managing sewage sludge is reflected in their legislation and policy which complements their national strategy of fitting into a circular economy [55].

To date, policy regarding MPs has largely been focused on marine MP pollution, however, more attention is slowly being placed on MP's role in terrestrial systems [61]. The European Strategy for Plastics in a Circular Economy (ESPCE) was released in 2018; this plan was part of a wider strategy developed in 2015, the Circular Economy Action Plan, which identified plastics as a priority area. The focus is on reducing the amount of plastic that makes its way into the environment through reducing plastic production and increasing plastic packaging recycling by 2030. The link between MPs and WWTPs was mentioned once throughout. The mention stated that more research is needed within the sector; this is despite the numerous availability of research addressing the prominent link between WWTP/Sludge and MPs which has been documented before the release of the ESPCE in 2018. Overall, the strategy failed to mention any concrete measures for addressing MPs within the WWTP and sewage sludge. On a more progressive note, the Scientific Advice Mechanisms (SAM) Group, created by the EU commission to inform their decision-making, advised on broadening policy cover to prevent and reduce MP pollution. The recommendation states that soil-based MP pollution should be addressed to the same extent and reflected through policy as for marine MPs [61]. Directives that are suggested include those applicable to the application of sewage sludge as fertilizer [61]. The ban on manufactured MP has been considered by the European Commission; although the consideration is independent of any sewage sludge/wastewater frameworks, it would inevitably make a significant impact on sewage sludge composition.

Neither Directive 86/278/EEC nor national regulations in the Member States currently recognize or have limit values for MPs in sewage sludge [59]. As explored in the aforementioned directives, it can be observed that the interactions between the various policies allow for gaps and unclear relationships between sewage sludge and the circular economy. As technology advances remarkably in achieving a circular economy, it becomes clear that limitations are now governance-related, rather than technological [60]. The Open Public Consultation for the Evaluation of the Sewage Sludge Directive 86/278/EEC is a step forward in acknowledging the outdated frameworks and holds an opportunity to recognize emerging contaminants to work towards once again improving the quality of sewage sludge before it is applied on land.

\section{A Proposed High-Level Strategy for Sustainable Sewage Sludge Management}

The following figure (Figure 3) is a proposed high-level strategy for sustainable sewage sludge management, specifically for the EU. It involves multiple stakeholders and the links between each of them to achieve appropriate management moving forward. 
Governance: Policy, Regulation, Legislation

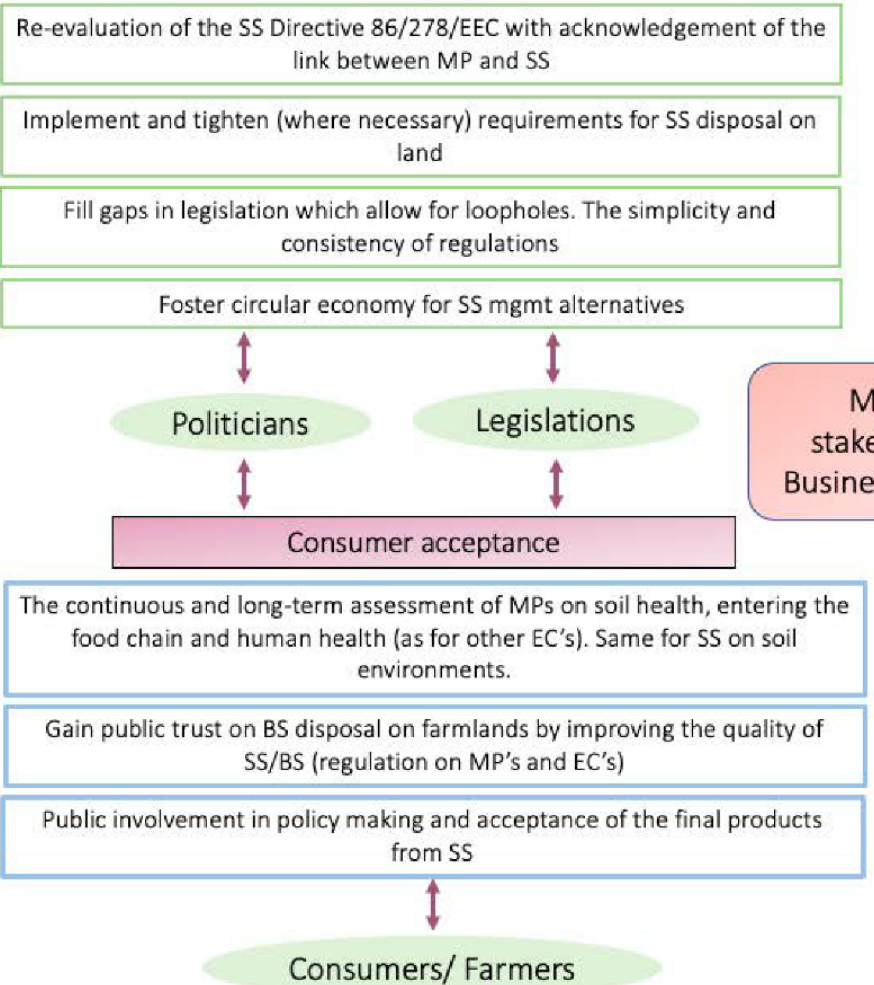

Technology

Finalization and release of MP standardisation protocol from the JRC

Optimisation of processes to achieve management of all residues from SS

Development of strategies to prevent MP release in WWTP

Target solutions to be applicable to the local and region context

Apply collaborative R\&D to share the risk, promote open innovations

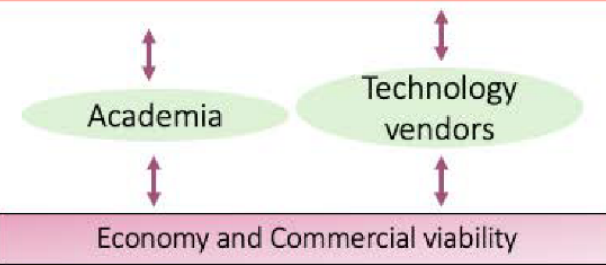

Apply a life cycle assessment with inclusion of MP fate and its tendencie in SS

Identify appropriate WWTP/ SS facilities where alternative methods of mgmt are profitable

Increase chance of market deployment for viable MP removal technologies and SS/SSA recovered products

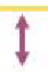

Investors / Plant owners

Figure 3. Proposed high-level strategy for sustainable sewage sludge management, specifically for the EU, SS—Sewage Sludge I MP—Microplastic | Mgmt—Management I WWTP—Wastewater treatment plant I SSA—Sewage Sludge Ash I JRC— Joint Research Centre I R\&D—Research and Development.

\subsection{Governance: Policy, Regulation, Legislation}

It can be concluded that legislation can be a key driver to accelerate the appropriate management of sewage sludge and ensure it fits in a circular economy while limiting both the accumulation and spread of MPs in the environment. So far, the link between MP and sewage sludge is not reflected in any policy or legislation around the world. Within the context of the EU, legislation needs to be amended to fill in gaps that have fostered uncertainty in its relation to sewage sludge, such as The Industrial Emissions Directive, The Waste Framework Directive, and Closing the loop-An EU Action Plan for the Circular Economy. Further, the re-evaluation of the sewage sludge Directive 86/278/EEC should aim to acknowledge the link between MP and sewage sludge with a tangible plan to limit its accumulation in soil and distribution in the environment. As several EU countries still use agricultural land as a primary method of sewage sludge disposal, any legislation that restricts this further should provide alternatives that keep sewage sludge in the frame of classifying it as a valuable resource rather than a waste product. A primary tool that is essential in the progression of acknowledging MP and sewage sludge is the adoption of standardized methods for its characterization, quantification and improve regulatory consistency for its reporting. Depending on the legislative body that acknowledges MPs, the strategy will differ. For example, if stringent limits are placed on MPs in WWTP effluent, the likely result will be that WWTP adopts centralized procedures (MP removal at the WWTP) [10]. Whereas, if it is mentioned in the sewage sludge Directive, the focus may be placed on source control/preventative techniques or increased incineration of sewage sludge. Changes to the Wastewater Directive would likely impact all land-based sources and there would be shared responsibility [10]. Recognition of MP's should not be the only amendment to the legislation, as even their removal will not improve sludge quality if other emerging contaminants are still present. The legislation should aim to set 
stricter limit values on emerging contaminants which can foster improved sewage sludge quality appropriate for land application; inspiration for such values can be taken from other European countries which have implemented more stringent limits.

\subsection{Economy and Commercial Viability}

Costs for sewage sludge management make up $20-60 \%$ of total operating costs despite sludge only accounting for $1-2 \%$ of the effluent volume [37]. The aim for sewage sludge treatment operators is to improve the quality of the BS to increase the value, decrease transportation costs, decrease the need for large storage areas, and have multiple management options for BS [62]. Sludge recycling is one of the most cost-effective ways to manage sludge, particularly when compared to incineration (Table 4). Therefore, for many countries, switching sewage sludge management completely away from the land application and diverting to more expensive technologies is not economically viable, especially in countries that do not have the current infrastructure already in place. However, to maintain environmentally appropriate land disposal, regulation will need to apply more stringent limitations on MP's and emerging contaminants present. This will inevitably result in increased amounts of sludge that do not pass the regulation to be disposed of on land and will need to undergo alternative management options. Therefore, increasing the chance of market deployment for viable sewage sludge recovered products e.g., construction materials, will make this transition economically possible. Additionally, the same can be applied to MP removal technologies. As explored earlier, it is more cost-effective to target $\mathrm{MP}$ at the source rather than targeting and removing them in the WWTP. Applying a life cycle assessment on the different management sewage sludge options (with the inclusion of MP fate) will provide relevant claims to support economic decisions. Furthermore, this can be achieved through identifying appropriate WWTP/sewage sludge facilities where alternative methods of management are profitable. Finally, where costs associated with more efficient processes for sewage sludge management hinder its implementation, legislation can also play a major role in its acceleration [32].

\subsection{Technology}

Legislation should reflect the importance of sewage sludge management options that are specific to the local and regional context. It is clear which management solutions have become detrimental in terms of their environmental impact, such as ocean disposal and landfilling. However, the same cannot be said for the opposite. There is no one-size-fits-all solution, instead, solutions should be tailored for the context of a region. Sludge management will depend on the region factors such as type of WWTP, people equivalent, or P content. Therefore, there is plenty of opportunity for innovation and sustainable technology that targets solutions to apply to the local and regional context. For example, optimization of processes to achieve management of all residues/waste streams from sewage sludge, whether that be its use on land, or when incinerated, upcycling residue ash [63]. When focusing on preventative and decentralized solutions for MP release (when it's not possible to simply implement a ban on the production of MPs), innovations are required in areas such as textile constructions, washing machine filters, guppy bags, and protective coatings. Innovations in decentralized treatments (those focused on removing MP at the WWTP) are also lacking and present an area that needs attention. Overall, all three areas for targeting MP removal (prevention, removal at WWTP, and appropriate management of sewage sludge) present opportunities for sustainable technology. Encouraging collaborative research and development in these areas will share the risk and promote open innovations to continue and increase.

\subsection{Consumer Acceptance}

Consumer acceptance will inevitably always play a major role in environmental practices. To gain public trust, the continuous and long-term assessment of MPs on soil health, entering the food chain, and impact on human health (as for other emerging contami- 
nants) needs to be carried out. The same applies to sewage sludge on soil environments; in fact, consumer attitudes towards sewage sludge/BS have been the reason behind certain countries moving away from its use on farmland. Gaining public trust in BS application on agricultural land can be achieved by regulating MPs and emerging contaminants within sewage sludge/BS, thereby improving its overall quality and appropriateness for land disposal. Involving the public in policy decisions will also encourage public trust. Moreover, it allows members of the public to inform regulators on socio-economic features that might have previously missed consideration. For example, as the use of incineration plants increase, it is important to ensure they are given appropriate locations.

\section{Conclusions}

It has been estimated that a significant source of MPs comes from the land application of sewage sludge from WWTPs. Once in the soil, MPs have the opportunity to impact both terrestrial and aquatic ecosystems. To prevent MP from entering waterways, bans/substitutions can be introduced for MPs in PCP's and industrial products. Technologies to target the removal of MP from sludge are limited and not currently implemented at a large scale. Although such bans are possible for certain countries, a complete ban would not be economically possible for others, especially countries that heavily rely on agricultural disposal and do not have the infrastructure to handle sludge disposal through other methods. If the use of SS on land is to decrease, alternative management should still aim to view SS as a valuable product while limiting MP movement. Therefore, emphasis and focus should be placed on improving sludge quality to reach a composition appropriate for land use and improving soil fertility and carbon storage. Overall, no directives recognize or have limits for MPs in sewage sludge, instead, there are gaps and unclear relationships between policies. Therefore, a high-level strategy for sustainable sewage sludge management, specifically for the EU, was proposed. Achieving appropriate sewage sludge management heavily relies on governance, which has a knock-on effect with increasing economic and commercial viability of emerging technology and aiding consumer acceptance by public involvement and trust. More than one paradigm shift will be necessary to utilize sewage sludge in its most efficient way, especially as there is no one-size-fits-all solution, and this inevitably requires the collaboration of all stakeholders.

Supplementary Materials: The following are available online at https:/ / www.mdpi.com/article/10 .3390/en14196293/s1, Table S1: Literature focused on addressing MP in SS., Table S2: Search terms used for literature search. The latest search was conducted on 1st February 2021; databases used PubMed, ScienceDirect, Research Gate.

Author Contributions: Conceptualization, N.M. and A.C.-K.; methodology, N.M.; formal analysis, N.M. and A.C.-K.; investigation, N.M.; resources, N.M.; data curation, A.C.-K.; writing-original draft preparation, A.C.-K., N.M.; writing-review and editing, N.M., A.C.-K.; visualization, N.M.; supervision, A.C.-K.; funding acquisition, A.C.-K. All authors have read and agreed to the published version of the manuscript.

Funding: This research received no external funding.

Institutional Review Board Statement: Not applicable.

Informed Consent Statement: Not applicable.

Conflicts of Interest: The authors declare no conflict of interest.

\section{References}

1. Quecholac-Piña, X.; Hernández-Berriel, M.; Mañón-Salas, M.; Espinosa-Valdemar, R.; Vázquez-Morillas, A. Degradation of Plastics under Anaerobic Conditions: A Short Review. Polymers 2020, 12, 109. [CrossRef]

2. Plastics Europe. Plastics- the Facts 2020; Plastics Europe: Brussels, Belgium, 2020; Available online: https://www.plasticseurope. org/en/resources/publications/4312-plastics-facts-2020 (accessed on 7 September 2020). 
3. Horton, A.; Walton, A.; Spurgeon, D.; Lahive, E.; Svendsen, C. Microplastics in freshwater and terrestrial environments: Evaluating the current understanding to identify the knowledge gaps and future research priorities. Sci. Total. Environ. 2017, 586, 127-141. [CrossRef] [PubMed]

4. He, D.; Luo, Y.; Lu, S.; Liu, M.; Song, Y.; Lei, L. Microplastics in soils: Analytical methods, pollution characteristics and ecological risks. TrAC Trends Anal. Chem. 2018, 109, 163-172. [CrossRef]

5. Hou, L.; Kumar, D.; Yoo, C.; Gitsov, I.; Majumder, E. Conversion and removal strategies for microplastics in wastewater treatment plants and landfills. Chem. Eng. J. 2021, 406, 126715. [CrossRef]

6. Mahon, A.M.; O'Connell, B.; Healy, M.G.; O'Connor, I.; Officer, R.; Nash, R.; Morrison, L. Microplastics in sewage sludge: Effects of treatment. Environ. Sci. Technol. 2016, 51, 810-818. [CrossRef] [PubMed]

7. Sun, Q.; Ren, S.; Ni, H. Incidence of microplastics in personal care products: An appreciable part of plastic pollution. Sci. Total. Environ. 2020, 742, 140218. [CrossRef] [PubMed]

8. Napper, I.; Thompson, R. Release of synthetic microplastic plastic fibres from domestic washing machines: Effects of fabric type and washing conditions. Mar. Pollut. Bull. 2016, 112, 39-45. [CrossRef]

9. Carney Almroth, B.; Åström, L.; Roslund, S.; Petersson, H.; Johansson, M.; Persson, N. Quantifying shedding of synthetic fibers from textiles; a source of microplastics released into the environment. Environ. Sci. Pollut. Res. 2017, 25, 1191-1199. [CrossRef]

10. Fältström, E.; Anderberg, S. Towards control strategies for microplastics in urban water. Environ. Sci. Pollut. Res. 2020, 27, 40421-40433. [CrossRef]

11. Karlsson, T.; Arneborg, L.; Broström, G.; Almroth, B.; Gipperth, L.; Hassellöv, M. The unaccountability case of plastic pellet pollution. Mar. Pollut. Bull. 2018, 129, 52-60. [CrossRef]

12. Danso, D.; Chow, J.; Streit, W. Plastics: Environmental and Biotechnological Perspectives on Microbial Degradation. Appl. Environ. Microbiol. 2019, 85, e01095-19. [CrossRef]

13. Schuhen, K.; Sturm, M.T. Microplastic Pollution and Reduction Strategies. In Handbook of Microplastics in the Environment; Rocha-Santos, T., Costa, M., Mouneyrac, C., Eds.; Springer: Cham, Switzerland, 2020; pp. 1-33.

14. UNEP. Ecosystems and Biodiversity in Deep Waters and High Seas; UNEP Regional Seas Reports and Studies No. 178; UNEP/IUCN: Geneva, Switzerland, 2006.

15. Eunomia Research \& Consulting. Plastics in the Marine Environment. 2016. Available online: https://www.eunomia.co.uk/reportstools / plastics-in-the-marine-environment/ (accessed on 30 August 2021).

16. De Falco, F.; Gentile, G.; Avolio, R.; Errico, M.; Di Pace, E.; Ambrogi, V.; Avella, M.; Cocca, M. Pectin based finishing to mitigate the impact of microplastics released by polyamide fabrics. Carbohydr. Polym. 2018, 198, 175-180. [CrossRef] [PubMed]

17. Chiweshe, A.; Crews, P. Influence of household fabric softeners and laundry enzymes on pilling ratings and breaking strength. Text. Chem. Colorist Am. Dyest. Report. 2000, 32, 41-47.

18. European Parliament. Plastic microfibre filters for new washing machines by 2025. 2020. Available online: https://www.europarl. europa.eu/doceo/document/E-9-2020-001371_EN.html (accessed on 7 January 2021).

19. Hann, S.; Sherrington, C.; Jamieson, O.; Hickman, M.; Kershaw, P.; Bapasola, A.; Cole, G. Investigating Options for Reducing Releases in the Aquatic Environment of Microplastics Emitted By (But Not Intentionally Added in) Products; DG Environment of the European Commission: Brussels, Belgium, 2018.

20. Petsitis, X. Microplastic in Cosmetics-Alternatives for the sensory Profile. Euro. Cosmetics 2018, 10, 14-16.

21. McDevitt, J.; Criddle, C.; Morse, M.; Hale, R.; Bott, C.; Rochman, C. Addressing the Issue of Microplastics in the Wake of the Microbead-Free Waters Act-A New Standard Can Facilitate Improved Policy. Environ. Sci. Technol. 2017, 51, 6611-6617. [CrossRef] [PubMed]

22. Bennett, D. Microbeads and Microplastics in Cosmetic and Personal Care Products; Briefing Paper Number 7510; House of Commons Library: London, UK, 2017.

23. ECHA. Microplastics. 2021. Available online: https:/ / echa.europa.eu/hot-topics/microplastics\#: \{\}:text=In\%20January\%202019 \%2C\%20ECHA \%20proposed, their\%20release \%20to\%20the \%20environment.\&text=The \%20proposal \%20is \%20expected \%20to, of\%20microplastics\%20over\%2020\%20years (accessed on 14 December 2020).

24. UN WWDR. The United Nations World Water Development Report; United Nations: New York, NY, USA, 2017.

25. Freeman, S.; Booth, A.; Sabbah, I.; Tiller, R.; Dierking, J.; Klun, K.; Rotter, A.; Ben-David, E.; Javidpour, J.; Angel, D. Between source and sea: The role of wastewater treatment in reducing marine microplastics. J. Environ. Manag. 2020, 266, 110642. [CrossRef] [PubMed]

26. Bläsing, M.; Amelung, W. Plastics in soil: Analytical methods and possible sources. Sci. Total. Environ. 2018, 612, 422-435. [CrossRef] [PubMed]

27. van den Berg, P.; Huerta-Lwanga, E.; Corradini, F.; Geissen, V. Sewage sludge application as a vehicle for microplastics in eastern Spanish agricultural soils. Environ. Pollut. 2020, 261, 114198. [CrossRef]

28. Käppler, A.; Fischer, D.; Oberbeckmann, S.; Schernewski, G.; Labrenz, M.; Eichhorn, K.; Voit, B. Analysis of environmental microplastics by vibrational microspectroscopy: FTIR, Raman or both? Anal. Bioanal. Chem. 2016, 408, 8377-8391. [CrossRef]

29. Corradini, F.; Meza, P.; Eguiluz, R.; Casado, F.; Huerta-Lwanga, E.; Geissen, V. Evidence of microplastic accumulation in agricultural soils from sewage sludge disposal. Sci. Total. Environ. 2019, 671, 411-420. [CrossRef] 
30. ANZBP. ANZBP Preliminary Report on Microplastics Risk for the Australian and New Zealand Biosolids Industry; Australian \& New Zealand Biosolids Partnership; Australian Water Association: St. Leonards, Australia, 2020; Available online: https://www. biosolids.com.au/wp-content/uploads/ANZBP-Microplastics-Prelim-Report-2020-Web.pdf (accessed on 26 November 2020).

31. EU Science Hub. Finding the Right Methods for Measuring Microplastics in Water; EU Science Hub-European Commission: Brussels, Belgium, 2021; Available online: https:/ / ec.europa.eu/jrc/en/news/finding-right-methods-measuring-microplasticswater (accessed on 10 December 2020).

32. Shaddel, S.; Bakhtiary-Davijany, H.; Kabbe, C.; Dadgar, F.; Østerhus, S. Sustainable Sewage Sludge Management: From Current Practices to Emerging Nutrient Recovery Technologies. Sustainability 2019, 11, 3435. [CrossRef]

33. Záleská, M.; Pavlík, Z.; Pavlíková, M.; Scheinherrová, L.; Pokorný, J.; Trník, A.; Svora, P.; Fořt, J.; Jankovský, O.; Suchorab, Z.; et al. Biomass ash-based mineral admixture prepared from municipal sewage sludge and its application in cement composites. Clean Technol. Environ. Policy 2017, 20, 159-171. [CrossRef]

34. Okoffo, E.; Tscharke, B.; O’Brien, J.; O’Brien, S.; Ribeiro, F.; Burrows, S.; Choi, P.; Wang, X.; Mueller, J.; Thomas, K. Release of Plastics to Australian Land from Biosolids End-Use. Environ. Sci. Technol. 2020, 54, 15132-15141. [CrossRef]

35. Kosobucki, P.A. Chmarzyński and B. Buszewski. Sewage Sludge Composting. Pol. J. Environ. Stud. 2000, 9, $243-248$.

36. Tezel, U.; Tandukar, M.; Pavlostathis, S. Anaerobic Biotreatment of Municipal Sewage Sludge. Compr. Biotechnol. $2011,6,447-461$.

37. Rostami, F.; Tafazzoli, S.; Aminian, S.; Avami, A. Comparative assessment of sewage sludge disposal alternatives in Mashhad: A life cycle perspective. Environ. Sci. Pollut. Res. 2019, 27, 315-333. [CrossRef]

38. Mohajerani, A.; Karabatak, B. Microplastics and pollutants in biosolids have contaminated agricultural soils: An analytical study and a proposal to cease the use of biosolids in farmlands and utilise them in sustainable bricks. Waste Manag. 2020, 107, 252-265. [CrossRef] [PubMed]

39. Braun, M.; Mail, M.; Heyse, R.; Amelung, W. Plastic in compost: Prevalence and potential input into agricultural and horticultural soils. Sci. Total. Environ. 2021, 760, 143335. [CrossRef] [PubMed]

40. Rillig, M.; Ziersch, L.; Hempel, S. Microplastic transport in soil by earthworms. Sci. Rep. 2017, 7, 1362. [CrossRef]

41. Maaß, S.; Daphi, D.; Lehmann, A.; Rillig, M. Transport of microplastics by two collembolan species. Environ. Pollut. 2017, 225, 456-459. [CrossRef]

42. Ghabbour, E.; Davies, G.; Misiewicz, T.; Alami, R.; Askounis, E.; Cuozzo, N.; Filice, A.; Haskell, J.; Moy, A.; Roach, A.; et al. National Comparison of the Total and Sequestered Organic Matter Contents of Conventional and Organic Farm Soils. Adv. Agron. 2017, 146, 1-35.

43. FAO. The Future of Food and Agriculture-Alternative Pathways to 2050; Licence: CC BY-NC-SA 3.0 IGO; FAO: Rome, Italy, 2018; Volume 224.

44. Cole, A.; Paul, N.; de Nys, R.; Roberts, D. Good for sewage treatment and good for agriculture: Algal based compost and biochar. J. Environ. Manag. 2017, 200, 105-113. [CrossRef]

45. Zomer, R.; Bossio, D.; Sommer, R.; Verchot, L. Global Sequestration Potential of Increased Organic Carbon in Cropland Soils. Sci. Rep. 2017, 7, 15554. [CrossRef]

46. Hawken, P. Drawdown: The Most Comprehensive Plan Ever Proposed to Reverse Global Warmin; Penguin Books: London, UK, 2017.

47. Schreefel, L.; Schulte, R.; de Boer, I.; Schrijver, A.; van Zanten, H. Regenerative agriculture-the soil is the base. Glob. Food Secur. 2020, 26, 100404. [CrossRef]

48. Roskosch, A.; Heidecke, P. Sewage Sludge Disposal in the Federal Republic of Germany; German Enviornmental Agency: Dessau-Roßlau, Germany, 2018; Available online: https://www.umweltbundesamt.de/sites/default/files/medien/1410 /publikationen/190116_uba_fb_klaerschlamm_engl_bf.pdf (accessed on 9 October 2020).

49. Wijesekara, H.; Bolan, N.; Thangavel, R.; Seshadri, B.; Surapaneni, A.; Saint, C.; Hetherington, C.; Matthews, P.; Vithanage, M. The impact of biosolids application on organic carbon and carbon dioxide fluxes in soil. Chemosphere 2017, 189, 565-573. [CrossRef]

50. Gravuer, K.; Gennet, S.; Throop, H. Organic amendment additions to rangelands: A meta-analysis of multiple ecosystem outcomes. Glob. Chang. Biol. 2019, 25, 1152-1170. [CrossRef] [PubMed]

51. Mohapatra, D.; Cledón, M.; Brar, S.; Surampalli, R. Application of Wastewater and Biosolids in Soil: Occurrence and Fate of Emerging Contaminants. Water Air Soil Pollut. 2016, 227, 77. [CrossRef]

52. Gianico, A.; Braguglia, C.; Gallipoli, A.; Montecchio, D.; Mininni, G. Land Application of Biosolids in Europe: Possibilities, Con-Straints and Future Perspectives. Water 2021, 13, 103. [CrossRef]

53. EPA. Biosolids Technology Fact Sheet Land Application of Biosolids; United States Environmental Protection Agency: Washington, DC, USA, 2000.

54. Collivignarelli, M.; Abbà, A.; Frattarola, A.; Carnevale Miino, M.; Padovani, S.; Katsoyiannis, I.; Torretta, V. Legislation for the Reuse of Biosolids on Agricultural Land in Europe: Overview. Sustainability 2019, 11, 6015. [CrossRef]

55. Christodoulou, A.; Stamatelatou, K. Overview of legislation on sewage sludge management in developed countries worldwide. Water Sci. Technol. 2015, 73, 453-462. [CrossRef]

56. Eurostat. Sewage Sludge Production and Disposal from Urban Wastewater. 2019. Available online: https://ec.europa.eu/ eurostat/web / environment/water (accessed on 6 September 2019).

57. DG Environment. Environmental, Economic and Social Impacts of the Use of Sewage Sludge on Land Part II: Report on Options and Impacts; Milieu Ltd.: Brussels, Belgium, 2008; Available online: https:/ /ec.europa.eu/environment/archives/waste/sludge/pdf/ part_i_report.pdf (accessed on 3 January 2021). 
58. Schnell, M.; Horst, T.; Quicker, P. Thermal treatment of sewage sludge in Germany: A review. J. Environ. Manag. 2020, $263,110367$. [CrossRef] [PubMed]

59. Stubenrauch, J.; Ekardt, F. Plastic Pollution in Soils: Governance Approaches to Foster Soil Health and Closed Nutrient Cycles. Environments 2020, 7, 38. [CrossRef]

60. Smith, H.M.; Fantinel, F. Realising the circular economy in wastewater infrastructure-the role of governance. In Proceedings of the International Symposium for Next Generation Infrastructure, London, UK, 11-13 September 2017; Available online: https:/ / www.smart-plant.eu/images/news/SmithFantinel-ISNGI2017.pdf (accessed on 4 January 2021).

61. SAM. Environmental and Health Risks of Microplastic Pollution; Scientific Advice Mechanism (SAM), Publications Office: Luxembourg, 2019; Available online: https:/ / op.europa.eu/en/publication-detail/- /publication/f235d1e3-7c4d-11e9-9f05-01 aa75ed71a1/language-en/format-PDF/source-108645429 (accessed on 10 December 2020).

62. NRMMC. Guidelines for Sewerage Systems Biosolids Management; Australian Water Association: Artarmon, Australia, 2004.

63. Cieślik, B.; Konieczka, P. A review of phosphorus recovery methods at various steps of wastewater treatment and sewage sludge management. The concept of "no solid waste generation" and analytical methods. J. Clean. Prod. 2017, 142, 1728-1740. [CrossRef] 